\title{
ORAL TUMORS IN DOGS. CLINICAL ASPECTS, EXFOLIATIVE CYTOLOGY AND HISTOPATHOLOGY
}

\author{
NEOPLASIAS ORAIS EM CÃES. AVALIAÇÃO DOS ASPECTOS \\ CLÍNICOS, HISTOPATOLOGIA E CITOLOGIA ESFOLIATIVA
}

\author{
Cláudia Ronca Felizzola ${ }^{1}$ Angelo João Stopiglia ${ }^{2}$ Ney Soares de Araújo ${ }^{3}$
}

\section{SUMMARY}

In order to establish the diagnosis and prognosis of tumors of the oral cavity, a comparative study was carried out in 130 dogs considering age, sex, breed, clinical aspects, exfoliative cytology as well as histopathology. Exfoliative cytology revealed: $100 \%$ negative for benign non-odontogenic tumors, $97.91 \%$ negative benign odontogenic tumors and $77.92 \%$ positive for malignant tumors. Histopathology showed: 59.23\% malignant tumors $33.08 \%$ malignant melanoma, $9.23 \%$ squamous cell carcinoma, $5.38 \%$ osteosarcoma, $2.31 \%$ fibrosarcoma, $2.31 \%$ angiosarcoma, $1.54 \%$ malignant mesenchymal tumors, $1.54 \%$ malignant fibrohistiocytoma, $1.54 \%$ lymphoma, $0.77 \%$ leyomyosarcoma, $0.77 \% \%$ epithelioid sarcoma and $0.77 \%$ angiofibrosarcoma); $36.92 \%$ benign odontogenic tumors $(25.38 \%$ peripheral odontogenic fibroma, $10.0 \%$ ossifyng fibroma and $1.54 \%$ odontoma) in addition to $3.85 \%$ benign non-odontogenic tumors $(1.54 \%$ fibroma, $0.77 \%$ plasmocytoma, $0.77 \%$ pilomatrixoma and $0.77 \%$ giant tumor cells). These results permit us to conclude that exfoliative cytology was an efficient, safe, quick and noninvasive method and could be used for early evaluation of oral cancer.

Key words: oral cancer, exfoliative cytology, histopathology, dogs.

\section{RESUMO}

Objetivou-se o estudo comparativo em tumores de cavidade bucal de animais de espécie canina de acordo com sexo, faixa etária, raça, aspectos clínicos, citologia esfoliativa e histopatologia, para estabelecer diagnóstico dessas neoplasias, tendo sido utilizados 130 cães, encaminhados ao Hospital Veterinário (HOVET) da Faculdade de Medicina Veterinária e Zootecnia da Universidade de São Paulo. Os resultados obtidos na citologia esfoliativa foram: $100 \%$ de negativos para neoplasias benignas não odontogênicas; $97,91 \%$ de negativos para neoplasias benig-

\begin{abstract}
nas odontôgenicas e 77,92\% de positivos para neoplasias malignas. Obtiveram-se os seguintes resultados no exame histopatológico: neoplasias malignas - 59,23\% (melanoma 33,08\%, carcinoma epidermóide 9,23\%, osteossarcoma 5,38\%, fibrossarcoma $2,31 \%$, angiossarcoma 2,31\%, neoplasia mesenguimal maligna $1,54 \%$, fibrohistiocitoma $1,54 \%$, linfoma $1,54 \%$, leiomiossarcoma 0,77\%, sarcoma epitelióide 0,77\% e angiofibrossarcoma 0,77\%); neoplasias benignas odontogênicas 36,92\% (fibroma odontogênico periférico $25,38 \%$, fibroma ossificante $10,0 \%$ e odontoma $1,54 \%$ ) e neoplasias benignas não odontogênicas 3,85\% (fibroma $1,54 \%$, lesão de células gigantes $0,77 \%$, pilomatrixoma $0,77 \%$ e plasmocitoma 0,77\%). Concluiu-se que a citologia esfoliativa constitui-se em método eficaz, seguro, rápido e incruento na avaliação precoce de neoplasias de cavidade bucal de cães. Observando-se os aspectos clínicos, resultados citológicos e histopatológicos, pode-se fornecer diagnóstico preciso e, conseqüentemente, prognóstico para o paciente com lesão tumoral.
\end{abstract}

Palavras-chave: câncer oral, citologia esfoliativa, histopatologia, cães.

\section{INTRODUCTION}

In the USA, cancer is the most common cause of death in dogs, oral neoplasm being the fourth most frequent type of tumors (WITHROW \& MAC EWEN, 1995). In Brazil, however, there have been very few studies carried out on this subject. It is common to find benign and/or malignant tumors in the mouth of dogs (WITHROW \& MAC EWEN, 1995) and these neoplasms may originate in odontogenic or non-odontogenic tissue (COHEM $\boldsymbol{e t}$ al.,1962). Furthermore, dogs are the most affected

\footnotetext{
${ }^{1}$ MédicoVeterinário Doutorando do Departamento de Cirurgia, Faculdade de Medicina Veterinária e Zootecnia, Universidade de São Paulo (FMVZ-USP) R. Antônio Alves Magan, 124, 01251-150, São Paulo, SP. E-mail cfronca@usp.br. Autor para correspondência.

${ }^{2}$ Médico Veterinário Professor Titular, Departamento de Cirurgia, FMVZ-USP.

${ }^{3}$ Dentista, Professor Titular, Departamento de Estomatologia, Faculdade de Odontologia,USP 
animals for kind of problem, when compared to other species, such as cats, horses and cattle.

It has been hypothesized that male dogs are more susceptible to oral neoplasm than female ones (TODORROF \& BRODEY, 1979). However, in Brazil, studies have suggested that males and females seem to be equally affected (STOPIGLIA $\boldsymbol{e} t$ $\boldsymbol{a l}$. , 1992), in addition to older animals (DORN $\boldsymbol{e t}$ al., 1968). Although several different breeds are affected by the disease, it is more frequently observed in ones such as: German Pointer, Weimaraner, Golden Retriever, Boxer and Cocker Spaniel (DORN et al., 1976). In Brazil, the most affected breeds appear to be German Shepherd, Poodle, Irish Setter and Mongrel (STOPIGLIA et al., 1992). The most common sites for the development of neoplasms in the mouth are the gums, tonsils, lips, palate and tongue. The predisposition to affect one site or the other depends on the origin of the tumor (TODORROF \& BRODEY, 1979; WITHROW \& MAC EWEN, 1995).

Among the malignant neoplasms, the most frequent one orally is malignant melanoma, followed by squamous cell carcinoma and fibrosarcoma (TODOROFF \& BRODEY, 1979). The most observed benign odontogenic neoplasm is epulis, as it was previously named (GORLIN et al.,1959) or periferic odontogenic fibroma, as it is now called (BRODEY, 1960; WHITE, 1991). The most commonly found benign non-odontogenic neoplasm is fibroma (THILEN \& MACDEWELL, 1987). The majority of the malignant tumors and some of the odontogenic tumors produce bone lesions, of which the extent of compromise depends upon the location of the tumor (WHITE et al., 1985; TODOROFF \& BRODEY, 1979). Thoracic radiographyis able to indicate lung damage (TODOROFF \& BRODEY, 1979), however, only when lesions are larger than 5mm (HOYT \& WITHROW, 1984).

During pre-surgical examination, the esfoliative cytology technique can be performed, to detect squamous cell carcinoma, though it may also detect malignant melanoma and fibrosarcoma (FELIZZOLA, 1995) and has been proven to be a simple, quick and not traumatic method (CAVINA,1964; ARAÚJO, 1960; GOBBI, 1987, BELLI et al., 1989; CECOTTI, 1991). Nevertheless, it has been reported by some authors that this method does not replace biopsy (SANDLER et al., 1960; GOBBI et al., 1987; BELLI et al., 1989; CECOTTI, 1991) and is based on the decrease of cohesiveness found in tumor cells, which permit visualization even if not of epithelial origin (SHKLAR 1968).
The aim of this investigation was to study oral neoplasms in dogs, observing clinical and histopathological findings, aside from those related to esfoliative cytology, based on the classification proposed by Papanicolaou (FOLSON et al.1972).

\section{MATERIAL AND METHODS}

In this investigation, 130 male and female dogs, age ranging from 2 months to 17 years old, with oral tumors and which were admitted to the School of Veterinary Medicine (University of São Paulo) Veterinary Hospital (Department of Surgery and Division of Surgical and Clinical Pathology) from 1989 to 1994 in order to establish the diagnosis, prognosis and treatment, were studied. Animals were examined and evaluated according to evolution period and growth pattern of tumors and clinical signs. All dogs were submitted to head and chest radiographic examination in order to analyze bone damage and verify the existence of metastasis. The data was organized according to clinical state based on the TNM Classification, presented by the World Health Organization (WHO).

Sampling for esfoliative cytology was obtained through lesion scrapping followed by preparation of smears (at least 3 slides per dog). After fixing the slides in $100 \%$ alcohol, samples were sent to the Stomalogy Department at the School of Dentistry (University of São Paulo) and were evaluated according to the Papanicolaou criteria. (1913) All dogs were indicated for surgical treatment. Biopsy was performed through excision and the results were fixed in $10 \%$ formaldehyde and sent for histopathological examination.

\section{RESULTS}

According to sex distribution, it was observed that more males (75 cases, $57.69 \%$ ) were affected than females (55 cases, 42.31\%). Age ranged from 2 to 204 months, with a mean of 84 to 154 months. Malignant neoplasm evaluated apart from other tumors was mainly found in animals from 72 to 144 months old (30 cases, $23.07 \%$ of total of neoplasms) and benign non-odontogenic neoplasm affected dogs ranging from 108 to 156 months old. Breed distribution was as follows: mongrel dogs (40 cases, 30.76\%); German Shepherds (23 cases, 17.69\%); Boxer (10 cases, 7.70\%); Pekinese and Poodle (7 cases each, 5.33\%) and other breeds which had six or less cases.

Tumor growth, together with other clinical signs, was present in all cases, whatever the origin of the neoplasm. In cases of malignant 
neoplasm, 39 dogs $(30 \%)$ had a foul smell and 36 dogs (27.70) presented bleeding; 5 dogs (3.83\%) presented loss of teeth and one $\operatorname{dog}(0.77 \%)$ had muscle atrophy. Bleeding also occurred in 18 dogs $(13.85 \%)$ with benign odontogenic neoplasm and in 2 dogs (1.51\%) with benign non-odontogenic neoplasm.

Different evolution periods were observed among neoplasms: malignant ones ranged from 1 to 62 days (62 cases, 47.68\%); benign odontogenic ones from 31 to 93 days (18 cases, $13.85 \%$ ), and benign non-odontogenic neoplasms ranged from 1 to 93 days ( 3 cases; $2.31 \%$ ).

Growth pattern seemed to be inversely proportional to the evolution period for all kinds of neoplasms. That is, the faster and more progressive the growth pattern, the shorter the evolution time. Among malignant neoplasms, 50 cases (36.46\%) had fast and progressive growth, slow and progressive growth was present in 28 cases $(21.54 \%)$ of the benign odontogenic neoplasms and 3 cases $(2.31 \%)$ of the benign non-odontogenic ones.

Neoplasms occurred in certain sites of the mouth. Five places were frequently affected: gums, palate, lips, mouth floor and jugal mucosae and of these locations, the gums had the highest incidence of tumors. Five of five cases $(100 \%)$ of benign nonodontogenic neoplasms were located on the gums; and among the benign odontogenic neoplasms, 42 cases $(32.30 \%)$ were also found there; 3 cases $(2.31 \%)$ on the palate, 2 cases $(1.54 \%)$ on the roof of the mouth and one case $(0.77 \%)$ on the jugal mucosae. Among malignant neoplasms, 42 cases $(32.30 \%)$ were on the gums, 17 cases $(13.08 \%)$ on the palate, 10 cases $(7.69 \%)$ on lips, 5 cases $(3.85 \%)$ on the roof of the mouth and 3 cases $(2.31 \%)$ on the jugal mucosae.

The size of malignant neoplasms ranged from 4 to $10 \mathrm{~cm}$ (52 cases, $40 \%$ ); 5 to $8 \mathrm{~cm}(2.31 \%)$ for benign non odontogenic neoplasms, and from 0.1 to $4 \mathrm{~cm}$ (26 cases, $20 \%$ ) for benign odontogenic neoplasms.

When dealing with the physical aspects of the lesions, they were sessile in 58 cases $(44.06 \%)$ of malignant neoplasms and in 3 cases $(2.31 \%)$ of benign non-odontogenic neoplasms; and they were pedunculate in 36 cases $(27.69 \%)$ of benign odontogenic neoplasms. According to consistency, it was observed that the majority of the neoplasms were firm: 46 cases $(35.38 \%)$ among malignant neoplasms; 4 cases $(3.08 \%)$ among benign nonodontogenic neoplasms and 43 cases (33.07\%) among benign odontogenic neoplasms. Bone damage was found in 41 cases $(31.54 \%)$ of malignant neoplasms; 2 cases $(1.54 \%)$ of benign non-odontogenic neoplasms and 23 cases (17.69\%) of benign odontogenic neoplasms. Ulcers were present in 45 cases $(34.5 \%)$ of malignant neoplasms and 8 cases $(6.15 \%)$ of benign odontogenic neoplasms. Necrosis was found in 19 cases $(14.61 \%)$ of malignant neoplasms and one $(.77 \%)$ of benign odontogenic neoplasms. Neither necrosis, nor ulcers were observed among the cases of benign nonodontogenic neoplasms.

The TNM classification was obtained through the evolution of the size of the tumors, node involvement and presence of metastasis. Among the benign non odontogenic neoplasms, the most observed stage was group I (3 cases, $2.31 \%$ ), for the benign odontogenic neoplasms, the most common stage was the group II (22 cases, 16.82\%) and for malignant neoplasm, group III (46 cases, 35.98\%) was the most frequent one.

Upon evaluation of the exfoliative cytology, using classification by Papanicolauo, class II (negative) results were obtained for all the cases of benign non-odontogenic neoplasms. For benign odontogenic neoplasms, 47 in 48 cases were negative (class II and I) and only one case presented a false positive result (class III). Among the malignant neoplasms, 18 cases were false negative ( 2 cases class I and 16 cases class II), the rest of the cases were: class III (11); class IV (13) and class V (36). For malignant neoplasms 6 (14\%) negative cases, $38(86 \%)$ positive cases, and $6(14 \%)$ false negative cases were observed. Among squamous cell carcinomas, 3 cases $(25 \%)$ were negative, 9 cases $(75 \%)$ were positive, and 3 cases $(25 \%)$ false negative. Among the fibrosarcomas, 33 cases (100\%) were positive: one leyomiosarcoma and one ephitelioc Among osteosarcoma, 2 cases (28.6\%) were negative and 5 cases $(71.4 \%)$ were positive. For malignant mesemchymal tumor and lymphoma, there was one negative case $(50 \%)$ and one positive case $(50 \%)$. For the 2 cases of malignant fibrohistiocytoma and 3 cases of angiossarcoma, it was verified $100 \%$ of negative cases, that is $100 \%$ of false negative results. (table 1, figure 1)

Histopathological classification of the lesions was performed according to the embryonic origin and separated in three divisions: malignant neoplasm, benign non-odontogenic neoplasm and benign odontogenic neoplasm, as described in table1. Benign odontogenic neoplasms presented the following frequencies: 33 cases $(75.38 \%)$ were peripheric odontogenic fibroma; 13 cases (10\%) ossifying fibroma and 2 cases (1.54\%) odontoma. Among the benign non-odontogenic neoplasms, 2 cases $(1.54 \%)$ were fibroma; one case $(0.77 \%)$ was giant cell lesions, one case $(0.77 \%)$ plasmocytoma 
Table 1 - Exfoliative cytology, in class according to Papanicolaou, and histopathology distribution of malignant neoplasms (MN), nonodontogenic benign neoplasms (NOBN) and odontogenic benign neoplasms (OBN) in 130 dogs with oral tumors. São Paulo, Brazil, 1997.

\begin{tabular}{|c|c|c|c|c|c|c|}
\hline & CLASS I & CLASS II & CLASS III & CLASS IV & CLASS V & DOGS \\
\hline \multicolumn{7}{|c|}{ ODONTOGENIC BENIGN NEOPLASM } \\
\hline & 9 & 24 & & & & 33 \\
\hline Ossifying Fibroma & 3 & 9 & 1 & & & 13 \\
\hline Odontoma & & 2 & & & & 2 \\
\hline \multicolumn{7}{|c|}{ NON ODONTOGENIC BENIGN NEOPLASM } \\
\hline Fibroma & & 2 & & & & 2 \\
\hline Giant cell tumor & & 1 & & & & 1 \\
\hline Plasmocytoma & & 1 & & & & 1 \\
\hline Pilomatrixoma & & 1 & & & & 1 \\
\hline \multicolumn{7}{|l|}{ MALIGNANT NEOPLASM } \\
\hline Malignant Melanoma & 1 & 5 & 5 & 8 & 24 & 43 \\
\hline Squamous cell carcinoma & & 3 & & 2 & 7 & 12 \\
\hline Osteosarcoma & & 2 & 3 & 1 & 1 & 7 \\
\hline Angiosarcoma & & 3 & & & & 3 \\
\hline Fibrosarcoma & & & & 1 & 2 & 3 \\
\hline Fibrohistiocytoma & & 1 & & 1 & & 2 \\
\hline Limphoma & & 1 & & & 1 & 2 \\
\hline Malignant mesenchymal tumor & & 1 & 1 & & & 2 \\
\hline Angiofibrosarcoma & & & 1 & & & 1 \\
\hline Leyomyiosarcoma & & & & & 1 & 1 \\
\hline Epitelioid Sarcoma & & & 1 & & & 1 \\
\hline TOTAL & 13 & 56 & 12 & 13 & 36 & 130 \\
\hline
\end{tabular}

and one case $(0.77 \%)$ pilomatrixoma. Among the malignant neoplasms 44 cases were melanoma $(33.85 \%) \quad 12$ cases $(3.23 \%)$ squamous cell carcinoma; 7 cases $(5.38 \% 0$ osteosarcoma; 3 cases $(2.31 \%)$ fibrosarcoma and 3 cases $(2.31 \%)$ angiosarcoma. In addition 2 cases (1.54\%) were malignant mesenchymal tumors and malignant fibrohistiocytoma and lymphoma and there was one case $(0.77 \%)$ each of leyomiosarcoma and epitelioid sarcoma.

\section{DISCUSSION}

One hundred and thirty dogs presenting oral neoplasms of different origins, malignant or benign were studied and confirmed using the research of COHEM et al., (1964); DORN \& PRIESTER (1976); TODOROFF \& BRODEY (1979); HOYT \& WITHROW (1984).

It was observed that, in general, male subjects were more affected than females, a fact that was also verified by TODOROFF \& BRODEY (1979). However this data differs from that observed by STOPIGLIA et al. (1992), also working in Brazil.
In relation to age, older dogs were more also frequently affected, as also observed by DORN \& PRIESTER (1976), TODOROFF \& BRODEY (1979) as well as STOPIGLIA et al. (1992). Animals from seven to thirteen years old were the most affected; however, odontoma was also observed in animals of only 2 months of age. Comparing our data of the present study with that of TODOROFF \& BRODEY (1979), HOYT \& WITHROW (1984), an earlier occurrence of malignant neoplasms was observed than that which was found in the studies of these authors. In the present study, one 4 month old animal with squamous cell carcinoma and another 11 month old animal with malignant melanoma were evaluated.

In the study by DORN \& PRIESTER (1976), the most affected breeds were German Shepherd; Cocker Spaniel; Boxer; Golden Retriever and Weimaraner. Differing from this data, STOPIGLIA et al. (1992), encountered a higher index of mongrels; German Shepherd; Boxer, Poodle and Pekinese with this affliction, which was confirmed in the present study. Despite the variety of breeds investigated, mongrels were predominant, 


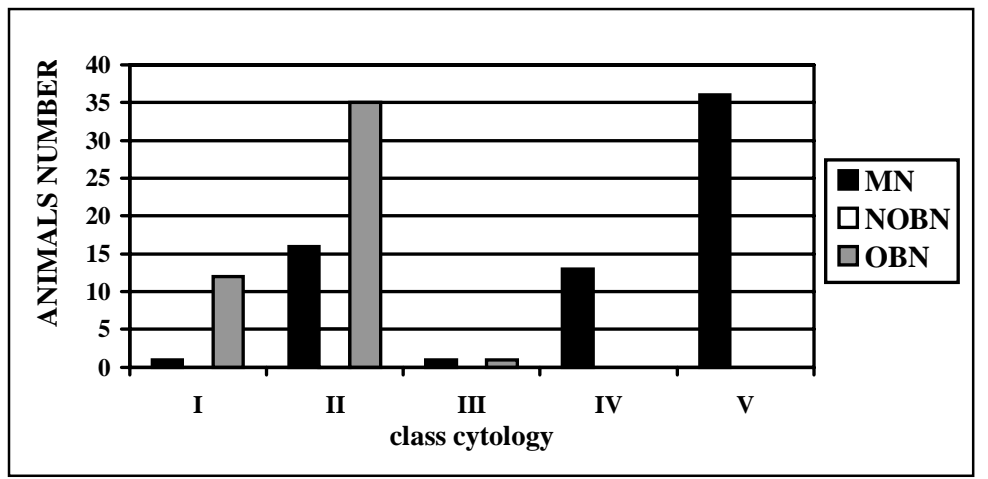

Figure 1 - Exfoliative cytology, in class according to Papanicolaou, distribution of malignant neoplasms (MN), non-odontogenic benign neoplasms (NOBN) and odontogenic benign neoplasms (OBN), in 130 dogs with oral tumors. São Paulo, Brazil, 1997.

which is an explanation for why they presented such a high incidence of oral neoplasms. Large dogs (weighing more than $23 \mathrm{~kg}$ ) had more malignant melanoma and squamous cell carcinoma (German shepherd, Fila Brasileiro, Irish setter), a fact also in agreement with the data by DORN \& PRIESTER (1976), but differing from that of TODOROFF \& BRODEY (1979) and HOYT \& WITHROW (1984).

Among clinical signs found related to all the neoplasms, tumor size increase was observed in every case. Other clinical signs varied with the pattern, location and stage of development of the neoplasm, as also elaborated by EMMS (1987). The period of evolution and growth of the neoplasm were similar to those found by HOYT \& WITHROW (1984).

In relation to the location of neoplasms in the month, they were more frequently found on the gums, palate, lips, mouth floor and jugal mucosae. Authors in the literature are unanimous in affirming that the gums are most common place to find oral tumors (DORN \& PRIESTER; 1976, TODOROFF \& BRODEY, 1979). This data was confirmed in our study.

Size of the lesions varied according to their origin, growth pattern and evolution period. Malignant neoplasms greater than $4 \mathrm{~cm}$ were encountered and among the benign non-odontogenic neoplasms, size ranged from 0.1 to $4 \mathrm{~cm}$. These values are greater than those observed by BRODEY (1970). In addition, it was also noted that more time elapsed for the animals to be treated.

As described by DUBELZIG (1982); benign odontogenic neoplasms were firm and pedunculate, and malignant neoplasms were firm, sessile, with the presence of ulcers and necrosis, similar to what was described by TODOROFF \& BRODEY (1979) and HOYT \& WITHROW (1984).
DORN et al. (1968) reported a predominance of malignant melanoma in animals presenting pigmented mucous membranes, a point also confirmed in the present study. Different from what was found by TODOROFF \& BRODEY (1979) and HOYT \& WITHROW (1984), no cases of tonsil squamous cell carcinoma were found, even when dealing with dogs which lived in an urban area WITHROW $^{\mathrm{a}}$ (1996- informe verbal), who stated that this kind of tumor is not currently found. Osteosarcoma, followed by fibrosarcoma, was the third in the ranking of most common kinds of neoplasms observed in this study, this differs from literature data by HOYT \& WITHROW (1984), who found this relation to be inverse.

GORLIN (1959) and DUBIELZIG (1982) gave the term epulides to benign odontogenic neoplasms. However, the classification by ARAÚJO \& ARAÚJO (1984) and BOSTOCK \& WHITE (1987) calls them ossifyng fibroma and peripheric odontogenic fibroma, for epulides means "only on the gums". There is certain controversy about the origin of odontomas. THILEN \& MADEWELL (1987) believe they are benign odontogenic neoplasms and ARAÚJO \& ARAÚJO (1984), affirm that they are a growth disorder.

Radiographic evaluation is extremely important to check bone damage. Four cases of benign odontogenic neoplasms ossifying fibroma were observed, with the presence of mineralized formations, as in agreement with WHITE (1991). Among malignant neoplasms, which had a bone lisis form, six cases of squamous cell carcinoma and 27 cases of malignant melanoma were studied, a finding similar to what was verified by TODOROFF \& BRODEY (1979).

Animals with radiographically evidenced thoracic metastases were not used in the present study. To be diagnosed, lesions have to be greater than $5 \mathrm{~mm}$ to be detected by radiographic examination. (HOTY \& WITHROW, 1984)

TNM classification was used. It was noted that the majority of benign non-odontogenic neoplasms were in-group I, benign odontogenic neoplasms in-group II and malignant neoplasms in group III. The majority of neoplasms were greater than $2 \mathrm{~cm}$ in size, differing from the data by TODOROFF \& BRODEY (1979). 
There seem to be no studies in Veterinary Medicine which involve esfoliative cytology. This technique is often used in human medicine and dentistry to detect squamous cell carcinoma. According to the origin of the tumor, results may be positive, negative, false positive or false negative. Among benign non-odontogenic neoplasms $100 \%$ of the negative results were found to be correct. Among benign odontogenic neoplasms, $97.91 \%$ were obtained, with only $2.09 \%$ of false positive results; however when histopathological examination was performed the process proved to be benign. On the other hand, $77.92 \%$ of the results were correct for malignant neoplasms and $23.18 \%$ of the results were false negative ones. In studies of squamous cell carcinoma involving human subjects using the esfoliative cytology technique, FOLSON et al. (1972) found 69\% of positive results and REDDY $\boldsymbol{e t}$ al. (1975), 63\%; SKHLAR et al. (1968), 85.65\%; GOBBI $\boldsymbol{e t}$ al., (1987) $100 \%$ as well as BELLI $\boldsymbol{e t}$ al. (1989) found $91 \%$. However, the results of the present study are important to emphasize that the comparisons made in this study are based on data of squamous cell carcinoma presenting different embryogenic origins. Among squamous cell carcinoma, $75 \%$ of positive results were obtained, which is more than what was found by FOLSON $\boldsymbol{e t}$ al. (1972) and REDDY et al. (1975), but less than what was found by SHKLAR et al. (1960); ARAÚJO \& ARAÚJO (1984) and BELLI et al., (1989).

For malignant melanomas, $86 \%$ of positive results were found and only $14 \%$ were false negative ones. Many times, it was possible to see melanocites in the esfoliative cytology, and an early diagnosis was obtained. We also observed $71.4 \%$ of positive results versus $28.6 \%$ of false negative ones for osteosarcoma, which is to be noted as a good result, for osteosarcoma is not of epithelial origin.

Tumors like fibrosarcoma, leyomiosarcoma, epitelioid sarcoma and angiofibrosarcoma presented $100 \%$ of positive results. For lymphoma, malignant mesenchymal neoplasm $50 \%$ of false negative results were encountered and of the malignant fibrohystocioma and angiosarcoma, $100 \%$ were false negative results. In fact, the number of cases studied can be considered as toofew to prove the efficacy of the method, even though these oral tumors are rare in dogs.

When dealing with tumors in Veterinary Medicine malignant melanoma, squamous cell carcinoma, fibrosarcoma and osteosarcoma appear to be the quite common, according to DORN et al. (1968); TODOROFF \& BRODEY (1979);
WITHROW \& MAC EWEN (1995). Using esfoliative cytology, $71.4 \%$ to $100 \%$ of positives result were obtained in our study. These results agree with the explanation by SHKLAR (1968) on the decrease in cohesiveness among tumor cells. That is why it is possible to even examine tumors which are not of epithelial origin or tumors without the presence of ulcers and produce an early diagnosis of these neoplasms. Among benign odontogenic neoplasms, it was observed $100 \%$ of negative results for peripheric odontogenic fibroma and odontoma and $92.3 \%$ for ossifying fibroma, proving that the method may be useful and effective. Some authors, like ARAÚJO (1965) consider biopsy as compulsory when results are positive. However, esfoliative cytology seems to be an accurate method which does not cause any tissue damage (ARAÚJO, 1965). a point that our study agrees with, for the method is painless and not cruel and does not present risk of contamination to other sites with tumor-type cells, which can occur when using biopsy (MENENDEZ, 1981). It is also more practical, for it is not necessary to use anesthesia on the animal.

Similar to what was observed by STOPIGLIA et al. (1992), our study found more malignant neoplasms (59.53), followed by benign odontogenic neoplasms $(36.92 \%)$ and benign nonodontogenic neoplasms $(3.85 \%)$. The most frequent malignant tumors were malignant melanoma and squamous cell carcinoma, in that order, in agreement with the data of WITHROW \& MAC EWEN (1995). The third and fourth in the ranking of most common tumors were osteosarcoma and fibrosarcoma, which is in disagreement with WITHROW \& MAC EWEN (1995). Less common tumors were also observed such as angiosarcoma, malignant mesenchymal neoplasm, epithelioid sarcoma, malignant fibrohistocitoma, lymphoma, and angiofibrosarcoma. Most of them are rare in veterinary medicine. Among benign odontogenic neoplasms, three kinds of tumors were observed: peripheric odontogenic fibroma, ossifying fibroma and odontoma. Among benign non-odontogenic neoplasms it was observed: fibroma, plasmocytoma, pylomatixoma and giant cell lesion, which have not been cited in the literature.

Based on this data, it is important that the practitioner thoroughly examine the mouth of dogs presenting signs of growth in that region. They should also note all the information that helps the diagnosis of the case. It is recommended that the practitioner use radiographic examination together with esfoliative cytology for it has proven to be a simple and effective method. Following these 
options surgical treatment should be indicated. It is then possible to give the owner information about the nature of the neoplasm and the probable postoperative prognosis.

\section{CONCLUSION}

$\begin{array}{cccc}\text { After studying } 130 & \text { dogs with oral } \\ \text { neoplasms according to clinical and } & \text { a }\end{array}$ histophatological aspects as well as esfoliative cytology the conclusion are that oral neoplasms affect more male than female subjects and were more frequent in animals older than 7 years of age. More frequently affected breeds were mongrels, German Shepherds, Poodles; Boxer and Pekinese. More common clinical signs were volume increase, bleeding and foul smell in the oral region, being that the gums were the most affected region. Esfoliative cytology was completely efficient to diagnose nonodontogenic benign neoplasms, odontogenic benign neoplasms and good diagnosing of malignant neoplasms. Malignant Melanoma was the most common type of malignant tumors. Peripheric odontogenic fibroma was the most frequent benign odontogenic neoplasm, and fibroma was the most frequent of the benign non-odontogenic neoplasms.

\section{PERSONAL COMUNICATION}

a - Veterinary Teaching Hospital CSU Fort Collins, Co USA, 1995 .

\section{REFERENCES}

ARAÚJO, N.S. Diagnóstico citológico de lesões da mucosa oral. Rev Bras Cirur, v. 49, p. 350-352, 1965.

ARAÚJO, N.S., ARAÚJO, V.C. Patologia bucal. São Paulo: Artes Médicas, 1984.

BELLI, E., PERSICO, M., FRIGIERI,M. Attendibilità della citologia esfoliativa nelle neoplasie del cavo orale. Minerva Stol, v. 38, p. 1197-1199, 1989

BOSTOCK, WHITE, D.E., WHITE, A.S. Classification and behaviour after surgery of canine "epulides". J Comp Path, v. 97, p.197-206, 1987.

BRODEY, R.S. A clinical and pathologic study of 130 neoplasm of the mouth and pharynnx in the dog. Am J Vet Res, v. 21, p. $787-812,1960$.

BRODEY, R.S. The biological behavior of canine oral and pharyngeal neoplasm. J Am Anim Pract, v. 11, p. 45-53, 1970.

CAVINA, C. La citologia esfoliativa nella diagnosi dei tumori del cavo orale. Arc Stomatol, v. 5, p 485-507, 1964.

CECOTTI, E.L. Aplicacion de la citologia exfoliativa bucal al estudio da leucoplasia. Rev Assoc Odon Arg, v. 79, p. 41-42, 1991
COHEM, D., BRODEY, R.S., CHEN, S.M. Epidemiologic aspects of oral and pharyngeal neoplasm of the dog. Am J Vet Res, v.25, p. 1776-1780, 1964.

DORN, C.R., TAYLOR, D., SCHNEIDER, R et al.. Survey of animal neoplasis in Alameda, California II. Cancer morbity in dogs and cats from Alameda Country. J Nat Cancer Inst, v. 40 , p. $307-317,1968$.

DORN, C.R., PRIESTER, W.A. Epidemiologic analysis of oral and pharyngeal cancer in dogs, cats, horses and cattle. J Am Vet Med Assoc, v.167, p.1202-1206, 1976.

DUBIELZIG, R.R. Proliferative dental and gingival diseases of dog and cats. J Am Anim Hosp Assoc, v. 18, p. 577-584, 1982 .

DUBIELZIG, R.R., GOLDSCHMIDT,M.H,BRODEY, R.S. The nomenclature of periodontal epulides in dogs. Vet Path, v. 16, p. $209-214,1979$.

EMMS, S.G. The management of oral tumours in the dogs and cats. Austr Vet J, v. 64, p. 22-25, 1987.

FELIZZOLA, C.R. Estudo comparativo das neoplasias bucais em cães. Avaliação dos aspectos clínicos, da histopatologia e citologia esfoliativa São Paulo-SP. 80 p. Tese (Mestrado em Cirurgia )- Curso de Pós-graduação em Medicina Veterinária, Universidade de São Paulo, 1995.

FOLSOM, T.C., WHITE,C.P., BROMER, L.B.A, et al. Oral exfoliative study: Review of the literature and report of a three-year study. Oral Surg, Oral Med, Oral Path, v. 33, n. 1, p. 61-72, 1972.

GOBBI, R., PAVANELlO, W., MANACORDA, M., $\boldsymbol{e} \boldsymbol{t}$ al. L'esame citologico nella diagnose delle neoplasie epiteliali orali. Dental Cadmos, v. 55, p. 61-71, 1987.

GORLIN, R.J., BARROW, C.N., CHAUDHRY, A.P., et al. The oral and pathology of domestic animals. A study of 487 cases. Am J Vet v. 20, p. 1032-1061, 1959.

HOYT JR., R.F., WITHROW, , S.J. Oral malignancy in the dog. J Am Anim Hosp Assoc, v. 20, p. 84-92, 1984.

MENENDÉZ, O.R. Biopsia y citologia exfoliativa en estomatologia. Cecon, Argentina v. 6, p 23-32, 1981.

PAPANICOLAOU, G.N. Atlas of exfoliative cytology. The Commowealth Fund. Cambridge Mass: Harvard University, 1954. p. 1-21.

REDDY, C.R.R.M., KAMESWARI, V.R., PRAHLAD,D., $\boldsymbol{e}$ t al. Correlative study of exfoliative cytology and histopathology of oral carcinomas. J Oral Surg, v. 33, p. 435-438, 1975.

SANDLER, H.C., STAHL, S., CAHN,L.R., et al. Exfoliative cytology for detetion of early mouth cancer. Oral Surg,Oral Med, Oral Path, v. 13, p. 994-1009., 1960..

SHKLAR, G., MEYER,I. CATALDO,E., et al. Correlated study of oral cytology and histopathology Oral Surg, Oral Med, Oral Path, v. 25, p. 61-70., 1968.

STOPIGLIA, A.J., DAGLI, M.L.Z., JULY, J.R., et. al. Diagnóstico diferencial das neoplasias localizadas nas gengivas de cães. In: CONGRESSO BRASILEIRO DE CLÍNICOS VETERINÁRIOS DE PEQUENOS ANIMAIS, 11., Fortaleza, 1988. Anais... Fortaleza: ANCLIVEPA, 1988. p.7. 
STOPIGLIA, A.J., FELIZZOLA, C.R.. DAGLI, M.L.Z et al. Estudo clínico e anatomo patológico das formações neoplásicas e não neoplásicas da cavidade bucal de cães. Comun Cient Fac Med Vet Zootec, Univ S. Paulo, v. 16, n. 1/2, p. 33-39, 1992

THILEN, G.H., MADEWELL, B.R. Veterinary cancer medicine. 2 ed. Philadelphia: Lea \& Febrier, 1987. Tumors of the digestive tract: p. 499-553.

TODOROFF, R.J.; BRODEY, R.S. Oral and pharyngeal neoplasia in the dog: a retrospective survey of 361 cases. $\mathbf{J}$ Am Anim Hosp Assoc, v.175, p.567-571,1979.

WHITE, R.A.S., GORMAN, N.T., WATKINS, S.B.,et al. The surgical management of bone-involved oral tumours in the dog. J Small Anim Pract, v. 26, p. 693-708, 1985.

WITHROW; S.J.; MAC EWEN, E.G. Tumors of the gastrointestinal system. In: WITHROW, S.J.; MAC EWEN, E.G. Clinical veterinary oncology. Philadelphia: Lippincott, 1989. p.177-189.

Ciência Rural, v. 29, n. 3, 1999. 